\title{
Analisis distribusi dan margin pemasaran ayam broiler dengan pakan herbal di Kecamatan Mandalle Kabupaten Pangkep
}

\author{
Analysis of distribution and marketing margins of broiler chickens with herbal feed in \\ Mandalle Sub-district, Pangkep Regency
}

\author{
Aisyah $^{1^{*}}$, Mihrani $^{1}$, Khaeriyah Nur $^{1}$ \\ ${ }^{1}$ Program Studi Agribisnis Peternakan,Politeknik Pertanian Negeri Pangkajene Kepulauan \\ *Corresponding author: aisyah906@yahoo.com
}

Diterima tanggal 04 Agustus 2019, Disetujui tanggal 30 Desember 2019

\begin{abstract}
Abstrak
Tataniaga membantu peternak dalam menyalurkan hasil ternaknya agar sampai kepada konsumen. Penelitian ini dilakukan untuk mengetahui bentuk distribusi pemasaran ayam broiler yang menggunakan pakan herbal; mengukur dan manganalisis keuntungan dan margin yang diperoleh lembaga pemasaran ayam broiler; mengukur dan manganalisis efisiensi pemasaran ayam broiler dengan pakan herbal di Kecamatan Mandalle, Kabupaten Pangkep. Penelitian dilaksanakan di beberapa tempat yang menjadi rantai tataniaga yaitu di peternakan/produsen (unit usaha program studi Agribisnis Peternakan kampus Politeknik Pertanian Negeri Pangkep), dan di pasar tradisional Kecamatan Mandalle selaku pedagang pasar/eceran. Penelitian dilaksanakan pada bulan April hingga Mei 2019. Metode yang digunakan yaitu analisis data secara kualitatif dan kuantitatif yaitu menggunakan analisis deskriptif dan matematis. Analisis deskriptif dimaksudkan untuk menguraikan secara kualitatif bentuk distribusi pemasaran ayam broiler yang menggunakan pakan herbal. Analisis matematis dimaksudkan untuk menghitung secara kuantitatif margin pemasaran, keuntungan tiap lembaga pemasaran, dan efisiensi pemasaran. Hasil penelitan ini menunjukkan bahwa distribusi pemasaran yang terbentuk hanya terdapat satu rantai tataniaga yaitu PeternakanPedagang Eceran-Konsumen. Distribusi pemasaran ayam broiler dengan pakan herbal di Kecamatan Mandalle ini cukup baik, efisien dan diterima masyarakat setempat. Margin pemasaran yaitu Rp. 5.000 (bobot hidup), keuntungan lembaga pemasaran sebesar Rp. 4.130/ekor; distribusi pemasaran dikategorikan efisien karena berada pada kisaran $0-33 \%$ yaitu $1,934 \%$.
\end{abstract}

Kata kunci: ayam broiler, pakan herbal, pola pemasaran, margin pemasaran, efisiensi pemasaran

\begin{abstract}
Commerce helps farmers in distributing their livestock products to consumers. This research was conducted to determind the distribution form of broiler marketing using herbal feed; measure and analyze the benefits and margins obtained by broiler chicken marketing agencies; measure and analyze the efficiency of marketing broiler chickens with herbal feed in Mandalle District, Pangkep Regency. This research was conducted in several places that became the commerce chain, namely in the farm/producer (business unit of the Animal Husbandry Agribusiness Study Program in the Pangkep State Polytechnic of Agriculture), and in the traditional markets of the Mandalle District as a market/retail trader. The study was conducted in April to May 2019. The method used is qualitative and quantitative data analysis using descriptive and mathematical analysis. Descriptive analysis is intended to describe qualitatively the marketing distribution form of broilers using herbal feed. Mathematical analysis is intended to quantitatively calculate marketing margins, the profit of each marketing institution, and marketing efficiency. The result of this research show that the marketing distribution that is formed only has one trading chain, namely Animal Husbandry-Retail MerchantsConsumer. The marketing distribution of broiler chickens with herbal feed in Mandalle District, is quite good, efficient and accepted by the local community. The marketing margin is Rp. 5.000 (kg of live weight), the profit of the marketing institution is Rp. $4.130 / \mathrm{kg}$; marketing distribution is categorized as efficient because it is in the range of $0-33 \%$, namely $1.934 \%$.
\end{abstract}

Keywords: broiler chicken, herbal feed, marketing pattern, marketing margin, marketig efficiency 


\section{PENDAHULUAN}

Populasi ayam broiler yang fluktuatif sementara kebutuhan akan protein hewani yang semakin tinggi akibat jumlah masyarakat yang tiap tahun terus meningkat khususnya di Kecamatan Mandalle, Kabupaten Pangkep memberi tantangan tersendiri bagi peternak budidaya ayam broiler untuk meningkatkan jumlah ketersediaan karkas ayam broiler secara cepat dan konstan. Pemberian pakan herbal dapat memperlihatkan performa ayam broiler yang lebih baik, karkas yang dihasilkan pun lebih sehat dengan kualitas lebih baik, serta tidak rentan terserang penyakit mematikan sehingga berimplikasi pada kemudahan pemasarannya dimana sebagian besar masyarakat mencari dan membutuhkan ayam broiler yang sehat dan berkualitas. Rata-rata hasil riset menunjukkan bahwa pemberian pakan herbal tidak berpengaruh nyata pada pertambahan bobot badan ayam broiler, namun tetap memperlihatkan perubahan yang signifikan ke arah performa yang lebih baik.

Tataniaga merupakan suatu bagian yang tidak dapat dipisahkan dari seluruh kegiatan usaha, begitu pula halnya dengan usaha peternakan ayam broiler. Tataniaga ayam broiler termasuk ke dalam subsistem agribisnis hilir, kegiatan ini dapat membantu peternak dalam menyalurkan hasil ternaknya agar sampai kepada konsumen. Tataniaga ayam broiler melibatkan berbagai lembaga tataniaga. Aktivitas tataniaga yang dilakukan oleh setiap lembaga tataniaga akan memberikan nilai tambah bagi komoditas yang diperjual-belikan. Nilai tambah yang dihasilkan perlu didistribusikan secara adil sesuai dengan faktor-faktor produksi yang digunakan sehingga nilai tambah dapat dirasakan oleh setiap lembaga tataniaga yang terlibat (Tarigan, 2014).

Kegiatan pemasaran produk ayam broiler dengan pakan herbal hingga sampai kepada konsumen di Kecamatan Mandalle, Kabupaten Pangkep melibatkan lembaga pemasaran yaitu peternak/produsen dan pedagang eceran/ pedagang pasar. Keuntungan yang diperoleh setiap lembaga/distribusi pemasaran tersebut dapat dipengaruhi oleh besarnya biaya dan margin pemasaran. Biaya pemasaran produk ayam broiler dengan pakan herbal yang relatif rendah akan berdampak pada keuntungan bagi pelaku distribusi pemasaran, dimana hal ini juga dipengaruhi oleh besarnya margin pemasaran. Margin pemasaran adalah selisih antara harga yang dibayar konsumen dengan harga beli produk. Jika margin pemasaran tinggi dengan biaya pemasaran yang rendah maka keuntungan yang diperoleh akan tinggi, begitupun sebaliknya. Efisien tidaknya kegiatan pemasaran ayam broiler dengan pakan herbal dapat diketahui dengan melihat perbandingan antara biaya pemasaran dan harga yang diberikan lembaga pemasaran kepada konsumen atau harga beli ayam broiler oleh konsumen. Berdasarkan hal tersebut, maka perlu diadakan penelitian mengenai aspek pemasaran komoditi ayam broiler yang menggunakan pakan herbal.

Tujuan penelitian ini adalah : (1) Mengetahui bentuk distribusi pemasaran atau rantai tataniaga ayam broiler yang menggunakan pakan herbal di Kecamatan Mandalle, Kabupaten Pangkajene Kepulauan serta perannya masing-masing; (2) Mengukur dan manganalisis margin dan keuntungan yang diperoleh lembaga distribusi pemasaran ayam broiler dengan pakan herbal di Kecamatan Mandalle, Kabupaten Pangkajene Kepulauan; dan (3) Mengukur dan manganalisis efisiensi pemasaran pada lembaga distribusi pemasaran ayam broiler dengan pakan herbal di Kecamatan Mandalle, Kabupaten Pangkajene Kepulauan.

\section{BAHAN DAN METODE}

\section{Waktu dan Tempat Penelitian}

Penelitian ini dilaksanakan di beberapa tempat yang menjadi rantai tataniaga pemasaran yaitu di peternakan/produsen dalam hal ini unit usaha program studi Agribisnis Peternakan kampus Politeknik Pertanian Negeri Pangkajene Kepulauan; di pasar tradisional kecamatan Mandalle selaku pedagang pasar/eceran. Penelitian dilaksanakan pada bulan April hingga Mei 2019.

\section{Teknik Pengumpulan Data}

Teknik pengumpulan data dilakukan dengan cara melakukan observasi/pengamatan dan pengambilan data langsung ke responden 
yang dijadikan sampel. Responden yang dijadikan sampel terdiri dari produsen, pedagang eceran/pedagang pasar dan pihakpihak terkait dengan rantai tataniaga pemasaran ayam broiler yang menggunakan pakan herbal. Jenis data yang digunakan pada penelitian ini bersifat kualitatif dan kuantitatif. Data yang bersifat kualitatif diperoleh dalam bentuk pengamatan dan wawancara, sementara data yang bersifat kuantitatif diperoleh dalam bentuk angka angka (numeric) dari hasil perhitungan dengan rumus. Sumber data yang digunakan dalam penelitian ini: 1) data primer yaitu data yang diperoleh langsung dari responden. 2) data sekunder yaitu data yang diperoleh dari sumber lain seperti literatur tentang distribusi pemasaran ayam broiler.

\section{Analisa Data}

Analisis data dilakukan secara kualitatif dan kuantitatif yaitu menggunakan analisis deskriptif dan matematis. Analisis deskriptif dimaksudkan untuk menguraikan secara kualitatif keadaan atau bentuk distribusi pemasaran ayam broiler dan menguraikan aktivitas pedagang ayam broiler. Analisis matematis dimaksudkan untuk menghitung secara kuantitatif margin pemasaran, keuntungan tiap lembaga pemasaran, dan efisiensi pemasaran. Analisis matematis dihitung menggunakan rumus sebagai berikut :

1. Margin pemasaran dihitung dengan rumus (Sudiyono, 2004 dan Rais, 2013) :

$M p=H k-H p$

Keterangan :

$\mathrm{Mp}=$ margin pemasaran $(\mathrm{Rp})$

$\mathrm{Hk}=$ Harga jual ayam broiler (Rp)

$\mathrm{Hp}=$ Harga beli ayam broiler $(\mathrm{Rp})$

2. Keuntungan yang diperoleh masing-masing lembaga pemasaran dihitung menggunakan rumus (Thalib, 2013 dan Hajar, 2016):

$\Pi=M-B p$

Keterangan :

$\Pi=$ Keuntungan Lembaga Pemasaran

$M=$ Margin Pemasaran

$\mathrm{Bp}=$ Biaya Pemasaran

3. Tingkat efisiensi pemasaran pada masingmasing saluran pemasaran dihitung menggunakan rumus (Rosmawati, 2011 dan Hajar, 2016):

$E p s=\frac{B p}{H E} \times 100 \%$

Keterangan:

Eps = Efisiensi Pemasaran

$\mathrm{Bp}=$ Biaya Pemasaran

$\mathrm{HE}=$ Harga Eceran

Dengan asumsi :

a. $0-33 \%=$ Efisien

b. $34-67 \%=$ Kurang Efisien

c. $68-100 \%=$ Tidak Efisien

\section{HASIL DAN PEMBAHASAN}

\section{Distribusi Pemasaran}

Berdasarkan hasil penelitian menunjukkan bahwa bentuk distribusi pemasaran ayam broiler yang menggunakan pakan herbal di Kecamatan Mandalle, Kabupaten Pangkep hanya terdapat satu pola distribusi pemasaran dan merupakan distribusi pendek karena hanya terdapat satu pedagang perantara, yaitu pedagang pasar/pengecer. Hasanah, et al. (2017) menyatakan bahwa distribusi pendek merupakan saluran pemasaran yang hanya menggunakan satu pedagang perantara. Bentuk distribusi pemasaran tersebut disajikan pada Gambar 1.

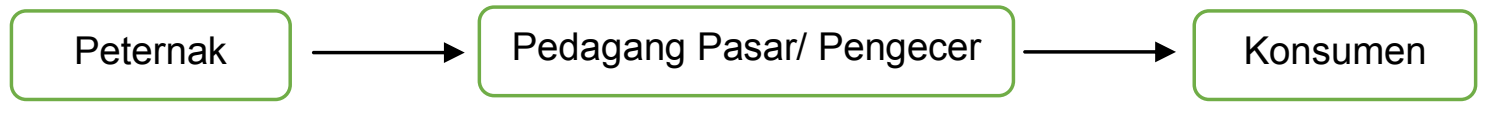

Gambar 1. Bentuk distribusi pemasaran menggunakan satu pedagang perantara

Peternak ayam broiler dengan pakan herbal adalah peternak yang mengusahakan (berternak) ayam potong dengan menggunakan pakan herbal, serta merupakan milik instansi (Prodi Peternakan Politeknik Pertanian Negeri Pangkep) sebanyak 64 ekor dengan bobot 
hidup berkisar $0,88 \mathrm{~kg}$. Pedagang pasar/pedagang eceran adalah kelompok pedagang yang kegiatannya memasarkan produk karkas ayam broiler dengan pakan herbal (bersih dari darah, kepala, ceker, bulu dan jeroan) kepada konsumen atau masyarakat. Dari 64 ekor ayam broiler yang diternakkan, sebanyak 61 ekor yang berhasil dipanen, sisanya sebanyak 3 ekor mengalami kematian, sehingga yang dijual atau dipasarkan ke pedagang eceran hanya 60 ekor.

Tiap lembaga pemasaran yang terkait dalam distribusi ini memiliki peran/fungsi yang berbeda. Fungsi masing-masing lembaga pemasaran tersebut dapat dilihat pada Tabel 1.

Tabel 1. Fungsi lembaga pemasaran ayam broiler dengan pakan herbal.

\begin{tabular}{|c|c|c|c|}
\hline No & Lembaga Pemasaran & Fungsi Pemasaran & $\begin{array}{c}\text { Kegiatan/Hubungan } \\
\text { Fungsi }\end{array}$ \\
\hline \multirow[b]{3}{*}{1.} & \multirow[b]{3}{*}{ Peternak } & Fungsi Pertukaran & Penjualan \\
\hline & & Fungsi Fisik & Pengangkutan \\
\hline & & $\begin{array}{l}\text { Fungsi Penyediaan } \\
\text { Sarana }\end{array}$ & $\begin{array}{c}\text { Penanggungan risiko } \\
\text { Pembiayaan } \\
\text { Pemeliharaan }\end{array}$ \\
\hline \multirow{3}{*}{2.} & \multirow{3}{*}{$\begin{array}{c}\text { Pedagang } \\
\text { Pasar/Pengecer }\end{array}$} & Fungsi Pertukaran & $\begin{array}{l}\text { Pembelian } \\
\text { Penjualan }\end{array}$ \\
\hline & & Fungsi Fisik & $\begin{array}{c}\text { Pengangkutan } \\
\text { Pemrosesan Penyimpanan }\end{array}$ \\
\hline & & $\begin{array}{l}\text { Fungsi Penyediaan } \\
\text { Sarana }\end{array}$ & $\begin{array}{c}\text { Penanggungan risiko } \\
\text { Pembiayaan }\end{array}$ \\
\hline
\end{tabular}

Sistem pemasaran pada saluran atau pola ini yaitu produsen dalam hal ini Prodi Agribisnis Peternakan Politeknik Pertanian Negeri Pangkep langsung memasarkan hasil panen berupa produk ayam broiler dengan pakan herbal ke pedagang pasar/eceran menggunakan mobil pengangkutan yaitu pick up yang disewa oleh pedagang pengecer. Pedagang pengecer membeli ayam broiler langsung dari produsennya dalam keadaan hidup. Kemudian pedagang pasar/eceran menjual ayam broiler tersebut kepada konsumen sudah dalam bentuk karkas yaitu dalam keadaan bersih dari darah, kepala, ceker, bulu dan jeroannya. Tarigan (2014) menyatakan bahwa dalam suatu distribusi pemasaran, peternak melakukan fungsi penjualan hasil panen mereka berupa ayam broiler hidup langsung kepada pedagang pengecer. Pedagang pengecer melakukan fungsi pembelian dan penjualan. Fungi pembelian dilakukan ketika membeli ayam broiler hidup hasil panen peternak, sementara fungsi penjualan dilakukan untuk menjual ayam broiler yang telah melewati proses pengolahan yang dilakukan oleh pedagang pengecer sehingga menjadi karkas (daging ayam tanpa darah, kepala, ceker, bulu dan jeroan) yang siap dijual kepada konsumen akhir. Pedagang pengecer melakukan fungsi pengangkutan, fungsi pengolahan dan fungsi penyimpanan. Fungsi pengangkutan dilakukan saat pedagang pengecer membeli ayam broiler hidup dari peternak, sementara fungsi pemrosesan/ pengolahan dilakukan saat pedagang pengecer mengolah ayam broiler hidup dengan melakukan pemotongan dan pencabutan bulu sehingga menjadi karkas siap jual. Fungsi penyimpanan dilakukan jika dalam 1 hari masih ada sisa karkas yang tidak terjual. Daging karkas tersebut kemudian di simpan dalam kotak berbahan sterofoam menggunakan es batu sebagai media pendigin.

Lebih lanjut Tarigan (2014) menyatakan bahwa fungsi fasilitas yang dilakukan oleh peternak pada saluran ini adalah fungsi penanggungan risiko dan fungsi informasi pasar. Fungsi penanggungan risiko dapat berasal dari fluktuasi harga yang dapat menyebabkan peternak mengalami kerugian jika harga jual sedang rendah dan berada di bawah harga pokok produksi (HPP). Fungsi 
informasi pasar diperlukan peternak untuk mengetahui harga jual beli ayam broiler hidup dipasaran. Fungsi fasilitas yang dilakukan oleh pedagang pengecer antara lain fungsi penanggungan risiko, fungsi pembiayaan dan fungsi informasi pasar. Fungsi penanggungan risiko dialami oleh pedagang pengecer jika terjadi fluktuasi harga di pasar terutama ketika harga sangat tinggi, hal tersebut menyebabkan dagangan pedagang pengecer sulit terjual, kemudian jika terdapat karkas yang tidak terjual dalam 1 hari sehingga dilakukan kegiatan penyimpanan dimana karkas tersebut akan dijual kembali pada esok hari. Fungsi pembiayaan yang dilakukan oleh pedagang pengecer diperlukan untuk permodalan usaha, antara lain biaya sewa kios dipasar tradisional, biaya restribusi dan biaya pengangkutan daging karkas dari peternak. Fungsi informasi pasar dibutuhkan oleh pedagang pengecer berupa harga jual dipasaran yang berlaku guna menentukan harga jual daging karkas mereka, juga informasi pasokan ayam broiler hidup berupa informasi peternakan yang sedang melakukan pemanenan.

\section{Margin Pemasaran}

Margin pemasaran yaitu selisih harga jual produsen dengan harga beli konsumen. Komponen margin pemasaran pada saluran pemasaran dalam penelitian ini dapat dilihat pada Tabel 2.

Tabel 2. Margin pemasaran ayam broiler dengan pakan herbal pada di Kecamatan Mandalle, Kabupaten Pangkep.

\begin{tabular}{lccc}
\hline \multicolumn{1}{c}{$\begin{array}{c}\text { Distribusi } \\
\text { Pemasaran }\end{array}$} & $\begin{array}{c}\text { Harga Jual } \\
\text { (Rp/ekor) }\end{array}$ & Harga Beli (Rp/ekor) & $\begin{array}{c}\text { Margin Pemasaran } \\
\text { (Rp) }\end{array}$ \\
\hline Peternak & 40.000 & - & - \\
\hline $\begin{array}{l}\text { Pedagang Pasar } \\
\text { Pengecer }\end{array}$ & 45.000 & 40.000 & 5.000 \\
\hline Total Margin & & & 5.000 \\
\hline
\end{tabular}

Total margin pemasaran ayam broiler dengan pakan herbal (Tabel 2) pada distribusi pemasaran atau rantai tataniaga diperoleh sebesar Rp. 5.000,-, dimana harga jual ayam broiler dengan pakan herbal yang diberikan peternak sebesar Rp. 40.000,- sementara harga beli konsumen yaitu sebesar Rp. 45.000. Ali (2014 dalam Mandak, et al. 2017) menyatakan bahwa margin merupakan perbedaan harga atau selisih harga yang dibayar konsumen akhir dengan harga yang diterima oleh peternak.

Distribusi pemasaran ayam broiler dengan pakan herbal di Kecamatan Mandalle Kabupaten Pangkep hanya ditemukan satu pedagang perantara yaitu pedagang pengecer sehingga bentuk saluran distribusinya dikatakan pendek, hal ini mempengaruhi besarnya margin pemasaran sehingga berdampak pada besarnya keuntungan yang diperoleh lembaga pemasaran. Amalia et al. (2013) menyatakan bahwa semakin banyak pedagang perantara yang terlibat maka semakin besar pula margin pemasaran yang terbentuk.

Selanjutnya Andhika et al. (2014) menyatakan semakin pendek saluran distribusi maka margin pemasaran akan semakin kecil/berkurang. Margin merupakan salah satu indikator yang digunakan untuk mengukur tingkat efisiensi suatu sistem pemasaran. Besarnya keuntungan yang diterima oleh masing-masing pelaku pemasaran relatif terhadap harga yang dibayar konsumen dan atau relatif terhadap biaya pemasaran terkait dengan peran yang dilakukan oleh masingmasing pelaku pasar.

Berdasarkan penelitian Andhika et al. (2014) tentang pengaruh rantai tataniaga terhadap efisien pemasaran daging sapi di Kabupaten Karo diketahui bahwa biaya pemasaran keuntungan yang terkecil diterima oleh pedagang pasar pada saluran III (Peternak-Pedagang Pengumpul - RPH Pedagang Pasar- Konsumen), sedangkan keuntungan tertinggi diperoleh pedagang pasar 
pada saluran I (Peternak-Pedagang PasarKonsumen). Hal ini dikarenakan saluran pemasaran yang dilalui cukup pendek sehingga dapat menekan biaya pemasaran dan margin pemasaran.

\section{Keuntungan Lembaga Pemasaran}

Keuntungan pemasaran ayam broiler dengan pakan herbal di pasar tradisional Kecamatan Mandalle Kabupaten Pangkep selain dipengaruhi oleh margin pemasaran juga dipengaruhi oleh besarnya biaya pemasaran. Rincian biaya pemasaran pada pedagang pasar/pengecer dapat dilihat pada Tabel 3 .

Semakin rendah biaya pemasaran, maka keuntungan yang diterima lembaga pemasaran semakin tinggi. Biaya pemasaran lebih sedikit dikarenakan hanya terdapat pedagang pengecer sebagai perantara dalam memasarkan produk ayam boiler agar bisa sampai ke tangan konsumen. Pedagang

Tabel 3. Rincian biaya pemasaran

\begin{tabular}{|c|c|c|}
\hline Variabel & Biaya & Biaya per ekor \\
\hline Pengangkutan (pick up) & $\mathrm{Rp} 20.000 / 0,88$ kg/60 ekor & $\operatorname{Rp} 378,8$ \\
\hline Retribusi & Rp 10.000/0,88 kg/60 ekor & $\operatorname{Rp} 189,4$ \\
\hline Penampungan & Rp 3.500.000/365 hari/0,88 kg/60 ekor & $\operatorname{Rp} 181,6$ \\
\hline \multirow[t]{2}{*}{ Pemotongan/Pemrosesan } & Rp. $6 \cdot 368 / 0,88$ kg/60 ekor & $\operatorname{Rp} 120,6$ \\
\hline & Total & $\operatorname{Rp} 870,4$ \\
\hline
\end{tabular}

pengecer hanya mengeluarkan biaya pengangkutan untuk membeli ayam broiler dengan pakan herbal dari peternak dan biaya retribusi, penampungan serta biaya pemotongan/pemrosesan dalam rangka melakukan penjualan/pemasaran ayam broiler dengan pakan herbal dalam bentuk karkas di pasar. Hal ini sesuai dengan pendapat Rasyaf
(1999 dalam Hasanah, et al. 2017) bahwa besar kecilnya biaya pemasaran yang dikeluarkan tergantung dari panjang pendeknya jalur pemasaran dan peran fungsi tata niaga. Tabel 4 menunjukkan besarnya biaya pemasaran dan keuntungan yang diperoleh masing-masing lembaga pemasaran.

Tabel 4. Biaya pemasaran dan keuntungan yang diterima oleh lembaga pemasaran.

\begin{tabular}{lcc}
\multicolumn{1}{c}{ Distribusi Pemasaran } & $\begin{array}{c}\text { Biaya Pemasaran } \\
\text { (Rp/ekor) }\end{array}$ & Keuntungan (Rp/ekor) \\
\hline Peternakan & - & - \\
Pedagang Pasar / Pengecer & 870,4 & $4.129,6-4.130$ \\
\hline Total & & 4.130 \\
\hline
\end{tabular}

Sumber : Data primer penelitian (2019)

Pada Tabel 4 menunjukkan bahwa keuntungan lembaga pemasaran yaitu pedagang pasar/pengecer adalah Rp. 4.130 per ekor. Keuntungan tersebut diperoleh dari hasil pengurangan margin pemasaran dengan biaya pemasaran. Sebagaimana diketahui bahwa margin pemasaran diperoleh sebesar Rp. 5.000,- kemudian dikurangi biaya pemasarannya sebesar Rp. 870,4 per ekor sehingga diperoleh hasil keuntungan pedagang pengecer sebesar Rp. 4.130 per ekor. Keuntungan yang diperoleh pada saluran distribusi ini cukup tinggi, hal ini dikarenakan biaya yang dikeluarkan untuk menjual ayam broiler dengan pakan herbal tidak terlalu besar, saluran distribusi pendek hanya menggunakan 
satu perantara dalam memasarkan hasil panen produk sehingga keuntungan yang diperoleh sangat tinggi. Hal ini sejalan dengan penelitian yang dilakukan Hasanah et al. (2017) tentang analisis saluran distribusi dan marginpemasaran telur itik di Kabupaten Situbondo memperoleh hasil bahwa keuntungan pedagang pengecer pada saluran distribusi pendek diperoleh dari harga jual telur itik dikurangi dengan harga beli dan biaya penjualan telur itik. Keuntungan yang didapat pada saluran distribusi pendek cukup tinggi, hal ini dikarenakan biaya yang dikeluarkan untuk menjual telur itik tidak terlalu besar, saluran distribusi pendek hanya menggunakan satu perantara dalam memasarkan telur itik sehingga keuntunganyang diperoleh sangat tinggi. Daniel (2002 dalam Hutasoit et al. 2017) menyatakan bahwa untuk mencapai keuntungan yang besar, maka lembaga pemasaran dapat melakukan langkah-langkah seperti menentukan harga jual sedemikian rupa sesuai dengan keuntungan yang dikehendaki dan meningkatkan volume penjualan sebesar mungkin.

\section{Tingkat Efisiensi Pemasaran}

Tingkat efisiensi pemasaran ayam broiler dengan pakan herbal di Pasar tradisional Kecamatan Mandalle Kabupaten Pangkep dapat dilihat pada Tabel 5. Pada Tabel 5 menunjukkan bahwa distribusi pemasaran efisien, karena diperoleh hasil perhitungan efisiensi pemasaran sebesar $1,934 \%$ berada pada kisaran $0-33 \%$ yang tergolong efisien. Rosmawati (2011) menyatakan bahwa efisiensi pemasaran jika nilai berada pada kisaran 0 - 33 $\%$ dikategorikan efisien, jika nilai pada kisaran $34-67 \%$ dikategorikan kurang efisien, dan jika nilai pada kisaran 68 - $100 \%$ dikategorikan tidak efisien.

Tabel 5. Efisiensi pemasaran ayam broiler dengan pakan herbal di Pasar Tradisional Kecamatan Mandalle, Kabupaten Pangkep.

\begin{tabular}{lccc}
\hline \multicolumn{1}{c}{ Distribusi Pemasaran } & $\begin{array}{c}\text { Biaya Pemasaran } \\
\text { (Rp/ekor) }\end{array}$ & $\begin{array}{c}\text { Harga Eceran } \\
\text { (Rp/ekor) }\end{array}$ & $\begin{array}{c}\text { Efisiensi } \\
\text { Pemasaran (\%) }\end{array}$ \\
\hline Peternak & - & - & \\
\hline $\begin{array}{l}\text { Pedagang Pasar / } \\
\text { Pengecer }\end{array}$ & 870,4 & 45.000 & $1,934 \%$ \\
\hline Total & & & $1,934 \%$ \\
\hline \multicolumn{2}{c}{ Sumber : Data primer penelitian (2019) }
\end{tabular}

Pemasaran produk peternakan berupa ayam broiler dengan pakan herbal di Kecamatan Mandalle, Kabupaten Pangkep adalah tentang bagaimana menyalurkan hasil panen peternakan tersebut dari produsen kepada konsumen dengan harga yang wajar dan biaya pemasaran yang minimal. Oleh karena saluran distribusi pemasaran ayam broiler dengan pakan herbal hanya terdapat satu perantara yaitu pedagang pengecer sehingga harga jual yang ditawarkan pedagang pengecer kepada konsumen masih dalam taraf wajar karena langsung mengambil hasil panen produk dari produsen/peternak, maka biaya pemasaran yang diperlukan agar produk sampai kepada konsumen akhir hanya sedikit. Menurut Soekartawi (1997), efisiensi pemasaran akan efisien jika biaya pemasaran lebih rendah daripada nilai produk yang dipasarkan, semakin rendah biaya pemasaran dari nilai produk yang dipasarkan, maka semakin efisien melaksanakan pemasaran.

Analisis margin dimaksudkan untuk mengetahui efisien atau tidaknya saluran distribusi pemasaran yang berlangsung. Semakin tinggi proporsi harga yang diterima produsen, maka semakin efisien sistem pemasaran tersebut. Proporsi harga yang diterima peternak/produsen dapat diketahui dari penghitungan total harga jual di tingkat peternak dibagi dengan total harga beli di tingkat konsumen dikalikan $100 \%$ sehingga diperoleh proporsi harga yang diterima peternak sebesar 88,89\%. Menurut Downeydan Erickson(1992 dalam Andhika et al. 2014) bahwa pemasaran hasil pertanian ditinjau dari 
bagian harga yang diterima oleh petani produsen dikatakan efisien apabila harga jual petani lebih dari $40 \%$ dari harga tingkat konsumen. Mengacu pada pendapat tersebut, hasil penelitian menunjukkan bahwa pemasaran ayam broiler dengan pakan herbal di Kecamatan Mandalle Kabupaten Pangkep sudah efisien, dengan harga yang dinikmati oleh produsen sebesar $88,89 \%$ terhadap harga di tingkat konsumen. Hasil perhitungan ini menunjukkan bahwa pemasaran ayam broiler dengan pakan herbal ditinjau dari bagian harga yang diterima oleh peternak sudah melebihi batas $40 \%$.

\section{KESIMPULAN}

Hasil penelitian ini menemukan bahwa terdapat satu bentuk distribusi pemasaran ayam broiler dengan pakan herbal di Kecamatan Mandalle, Kabupaten Pangkep yang merupakan saluran distribusi pendek yaitu $:$ Peternak $\rightarrow$ pedagang pengecer $\rightarrow$ konsumen.

Jumlah margin yang diperoleh sebesar Rp 5.000,-. Sedangkan keuntungan yang diperoleh yaitu sebesar Rp. 4.130 per ekor menunjukkan bahwa keuntungan yang diperoleh pada saluran distribusi pendek cukup tinggi, hal ini dikarenakan biaya yang dikeluarkan untuk menjual ayam broiler dengan pakan herbal tidak terlalu besar, dimana saluran distribusi pendek hanya menggunakan satu perantara dalam memasarkan hasil panen produk sehingga keuntungan yang diperoleh sangat tinggi.

Tingkat efisiensi distribusi pemasaran ayam broiler di pasar tradisional Kecamatan Mandalle, Kabupaten Pangkep sudah berlangsung secara efisien karena tingkat efisiensi saluran pemasaran tersebut berada pada kisaran 0 - 33\% yaitu sebesar 1,934\%. Efisiensi pemasaran dipengaruhi oleh panjang pendeknya saluran distribusi pemasaran, margin pemasaran, biaya pemasaran, dan keuntungan lembaga pemasaran. Distribusi pemasaran yang pendek dapat menekan biaya pemasaran dan margin pemasaran. Semakin rendah margin pemasaran maka semakin efisien distribusi pemasaran tersebut. Semakin pendek saluran distribusi maka margin pemasaran akan semakin kecil/berkurang.

\section{DAFTAR PUSTAKA}

Ali, I. 2014. Analisis margin pemasaran ternak sapi bali di Kecamatan Pulubala Kabupaten Gorontalo. Skripsi. Program Studi Peternakan. Universitas Gorontalo, Gorontalo.

Amalia, J A., Utami, H.D. dan Nugroho, B,A. 2013. Analisis pemasaran usaha ayam broiler skala kecil dan besar pada pola kemitraan PT Sinar Sarana Sentosa Malang. http://fapet.ub.ac.id/wpcontent/uploads/ 2013/04/AnalisisPemasaran-Usaha-Ayam-Broiler-SkalaKecil-Dan-Besar-Pada-Pola-KemitraanPT-Sinar-Sarana-Sentosa-Malang.pdf. Online. Diakses April 2019.

Andhika, R., Hasnudi, dan Ginting, N. 2014. Pengaruh rantai tataniaga terhadap efisiensi pemasaran daging sapi di Kabupaten Karo. Jurnal Petenakan Integratif Vol. 3(2): $224-234$.

Daniel, M. 2002. Pengantar Ekonomi Pertanian. Penerbit Bumi Aksara, Jakarta.

Downey dan Erickson. 1992. Manajemen Agribisnis. Erlangga. Jakarta.

Hajar, D.S. 2016. Kajian Pola Saluran dan Efisiensi Pemasaran Ayam Sentul (Studi Kasus Di Kelompok Peternak Barokah Abadi Farm Kabupaten Ciamis). Skripsi. Fakultas Peternakan Universitas Padjadjaran, Bandung.

Hasanah, L, Suryadi, U, dan Widhijanto, W. 2017. Analisis saluran distribusi dan margin pemasaran telur itik di Kabupaten Situbondo. Jurnal IImu Peternakan Terapan Vol. 1(1):25-30.

Hutasoit, G.P.E., Taslim, dan Paturochman, M. 2017. Analisis pola saluran dan marjin pemasaran ayam buras (studi kasus pada peternakan ayam buras Jimmy's Farm, Cipanas Kabupaten Cianjur, Jawa Barat). Artikel Ilmiah. Fakultas Peternakan Universitas Padjajaran, Bandung.

Mandak, Y., Rorimpandey, B., Waleleng, P.O.V. dan Oroh, F.N.S. 2017. Analisis margin pemasaran ayam broiler di pasar 
tradisional Kota Manado (Study kasus di Pasar Bersehati Calaca dan Pinasungkulan Karombasan). Jurnal Zootek Vol. 37(1):70-79.

Rais, F. 2013. Analisis Efisiensi Pemasaran Daging Sapi Di Pasar Sentral Kota Gorontalo. Skripsi. Program Studi Peternakan. Universitas Gorontalo, Gorontalo.

Rasyaf, M. 1999. Memasarkan Hasil Peternakan. Penebar Swadaya. Jakarta.

Rosmawati, H. 2011. Analisis efisiensi pemasaran pisang produksi petani di Kecamatan Lengkiti Kabupaten Ogan Komering Ulu . Jurnal Agronobis. Vol. 3 (5) : 1-9.
Soekartawi. 1997. Analisis Fungsi Produksi. PT. Raja Grafindo Persada, Jakarta.

Sudiyono, A. 2004. Pemasaran Pertanian. Malang, UMM Press.

Tarigan, J.F. 2014. Analisis Tataniaga Ayam Broiler di Kecamatan Parung Kabupaten BogorJawa Barat. Skripsi. Institut Pertanian Bogor, Bogor.

Thalib, F. 2013. Analisis margin pemasaran ayam pedaging di Kota Utara Kota Gorontalo. Skripsi. Program Studi Agribisnis. Universitas Gorontalo, Gorontalo. 